International Journal of Current Advanced Research

ISSN: O: 2319-6475, ISSN: P: 2319 - 6505, Impact Factor: SJIF: 5.995

Available Online at www.journalijcar.org

Volume 6; Issue 3; March 2017; Page No. 2755-2758

DOI: http://dx.doi.org/10.24327/ijcar.2017.2758.0099

Research Article

\title{
EXAMINATION OF NITRATE-NITRITE (NO3-NO2) ACCUMULATION OF BEETROOT AND SWEET POTATO, IN REGARD TO THE DEVELOPMENT OF THE METHEMOGLOBINEMIASYNDROME
}

\author{
F. Lantos ${ }^{1 *}{ }^{*}$, G. Szabó ${ }^{2}$., Z. Papp ${ }^{3}$., L. Jordan ${ }^{4}$ andE. Györgyi ${ }^{1}$ \\ 1University of Szeged Plant Sciences and Environmental Protection \\ Institute -Hódmezővásárhely, Andrássy str. 15.Hungary \\ ${ }^{2}$ Studium Generale Talent Development Foundation - Szentes, Hungary \\ ${ }^{3}$ Dr. Bugyilstván Hospital - Szentes, Hungary \\ ${ }^{4}$ Hungarian Food Safety Office - Budapest, Hungary
}

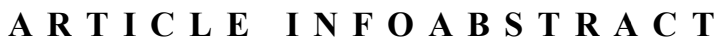

\section{Article History:}

Received $18^{\text {th }}$ December, 2016

Received in revised form $16^{\text {th }}$ January, 2017

Accepted $26^{\text {th }}$ February, 2017

Published online $28^{\text {th }}$ March, 2017

\section{Key words:}

sweetpotato, carrot, beetroot, methemoglobinemia
Although strictly controlled, vegetables complement the multifarious diet of babies, and it often happens that babies younger than 8-10 months are taken to hospital in critical condition due to nitrate poisoning. The disease is calledmethemoglobinemia. Mothersusuallyfeedtheirbabieshomemadecarrotpuree and thustheyprovidethe necessary carotene and vitamin A for them. In thebabies' stomachsthenitrate (NO3) will be released and,dueto the absence of a defencemechanism, it is transformedtonitrite (NO2). The nitriteoxidizestheoxygen-carrying hemoglobin $(\mathrm{Hb})$ and it becomesmethemoglobin $(\mathrm{MetHb})$. The MetHb is unsuitable for transporting oxygen, therefore, if $30-40 \% \mathrm{Hb}$ is transformed into MetHb, hypoxia occurs and, if at least $70-80 \%$ of $\mathrm{Hb}$ is transformed into $\mathrm{MetHb}$, then blue discoloration of mucous and respiratory failure occur. Beetroot and carrotaresusceptibletonitrateaccumulationrootvegetables. During its storage the amount of nitrate increases. However, it iswidelyusedforfreshconsumption and as a raw material for baby food. The sweetpotato (Ipomoeabatatas(L.) LAM) we examined, grownwithdifferenttechnologiesonsandysoil, didnotaccumulatenitrateabovethepermitted concentration of baby puree of limit of $200 \mathrm{mg} / \mathrm{kg}$. On the basis of our observation sweet potato is not susceptible to nitrate accumulation, therefore it mightreplacecarrotasrawmaterialfor baby food and homemadecarotenoid-richpuree in thefuture. Its growing is absolutely safe and profitable on sandy soil and other loose soil on small plots in the region of the South Plains of the Carpathian Basin. Production of sweetpotato, a member of theConvolvulaceae, productioncan be fitted intotheplantrotationdueit phylogeneticdissimilaritytoconventionallygrowncrops, therefore it cangreatlyenhancethesustainablehorticulture in Hungary.

Copyright $\mathrm{C} 2017 \boldsymbol{F}$. Lantos. This is an open access article distributed under the Creative Commons Attribution License, which permits unrestricted use, distribution, and reproduction in any medium, provided the original work is properly cited.

\section{INTRODUCTION}

The carrot (Daucuscarota spp. cativus L.)is one of the best vegetablestoprovidesufficient carotenesfor the human body; it has a centuries-old tradition of cultivation in temperate and Mediterranean countries of Europe. It contains a number of biological nutrients, it is easy to process and easily digestible and it can provide culinary delights for the consumer.Lantos, et al. (2016) published, the content of carotenes in carrot varieties is between $100-150 \mathrm{mg} / \mathrm{kgand}$ the water soluble carbohydrate (WSC) concentration is $80-90 \mathrm{~g} / \mathrm{kg}$, underthe

*Corresponding author:F. Lantos

University of Szeged, Hungary cultivation conditions of Hungary on average. The sugarcontent of the carrot root is usually a genetic character of the variety, but its value might be influenced both by thenutrient supply and the production technology (Uzoni, 2001). The research of Metlickij (1975) and Herrmann (1995) found that the carotenesin carrots increase in concentrationas the carrotroot grows and that $\alpha, \beta, \gamma, \zeta$ carotene are accumulated there. Due to its high nutritional value, carrot has become popular for fresh consumption and it is often used as raw material for different baby foods.Another frequent raw material for baby foods is the beetroot(Beta vulgaris subsp. vulgaris var. conditivaALEF.). Its particular importance in the nutrition of both infants and adults is the high calcium, phosphorus,iron andvitamin C, P, B1, B2 content (Balázs, 1994). In addition, the accumulation level of antioxidants is high in beetroot 
(Georgievet al., 2010). In respect of nitrate accumulation, the carrot belongs to the moderate category i.e. $500-1000 \mathrm{mg} / \mathrm{kg}$; 9-18 $\mathrm{mmol}$ as a root vegetable (Table 5.), however the beetroot belongs to a highly dangerous $2500 \mathrm{mg} / \mathrm{kg} ; 40 \mathrm{mmol}$ category (Bryan et al., 2010). After harvest, during storage, their nitrate concentration further increases, therefore it can be dangerous for making puree at home. The nitrate contentabove $200 \mathrm{mg} / \mathrm{kg}$ can cause fatal methemoglobinemia in infants.In the digestive system of babies younger than 8-10 months old there is nodiaphorase (NADH-cytochrome b5 reductase) enzyme that prevents the changeofnitrate (NO3) to nitrite (NO2). The nitrite oxidizes the oxygen-carrying haemoglobin ( $\mathrm{Hb})$ and it becomesmethemoglobin (MetHb). The MetHbis unsuitable for transporting oxygen, therefore, if $30-40 \% \mathrm{Hbis}$ transformed into MetHb, hypoxia occursand, if at least 70$80 \%$ of Hbis transformed intoMetHb,then blue discoloration of mucous and respiratory failure occurs(Tulupovet al. 2001).Canned baby foodsmade from carrot are strictly controlled by the producer, therefore their nitrate content is notharmful; however, homemade carrot puree has often caused blue baby syndrome because mothers are unaware of the problem.

Our aim was to find a vegetablethat has a nutritional composition similar to carrot and that is suitable for making both canned baby food and home-made carotene-rich purees. The plant selected was the sweet potato (Ipomoea batatas(L.) LAM) from the Convolvulaceae family, indigenousto South America and Africa. It was domesticated by the native people of Peru long ago; ancient sweet potato fossils from around 8000 B.C.provided evidence of human consumption (Loebenstein\&Thottapphilly, 2009). Global sweet potato production was approximately110 million tons in last few years (FAO).

\section{MATERIAL AND METHODS}

\section{Plant material}

Orange, purple and white sweet potato tubers were used from two Hungarian cultivation areas (Ásotthalom and Vámospércs) with sandy soils (Table 1.). nutrient supply method of sweet potato, or foreign-originated beetroots were obtained from Hungarian supermarkets.

\section{Nitrate and nitrite determinations}

Measurements were carried out in the laboratory of the Plant, Soil and Agricultural Environment Protection Directorate of Szolnok of National Food Chain Safety Office of Hungary. The nitrate-nitrite was determined using a FIAstar 5000 spectrophotometer with the local method ID: V-01-2013. The method is suitable for the determination of nitrate-nitrite content of vegetables and fruitsby linear regression in the range $0.5-5 \mathrm{mg} / \mathrm{dm} 3 \mathrm{NO} 3+\mathrm{NO} 2$ extract. The nitrate content of the sample was determined by the difference between theamount of nitrate-nitrite and the amount of nitrite (Polgárné\&Pásztor, 2013). The estimated uncertainty of the measurements and methodsoftheNational Food Chain Safety Office is shownin Table 2.

Table 2 Measuring methods of nitrate-nitrite.

\begin{tabular}{|c|c|c|c|}
\hline $\begin{array}{l}\text { Controled } \\
\text { compounds }\end{array}$ & $\begin{array}{c}\text { Measuringinterval } \\
(\mathrm{mg} / \mathrm{kg})\end{array}$ & $\begin{array}{l}\text { Indefication code of } \\
\text { methods }\end{array}$ & $\begin{array}{c}\text { Estimated } \\
\text { uncertainty of } \\
\text { the } \\
\text { measurements }\end{array}$ \\
\hline NO2(nitrite) & $>0,5$ & \multirow{3}{*}{$\begin{array}{c}\text { V-04: } 2013 \\
\text { V-01:2013 V-04: } 2013 \\
\text { V-02: } 2013 \text { V-04: } \\
2013 \\
\ldots\end{array}$} & \pm 3 rel. $\%$ \\
\hline NO3 (nitrate) & $5-50$ & & $3 \pm 5$ rel. $\%$ \\
\hline NO3 (nitrate) & $50-250$ & & \pm 4 rel. $\%$ \\
\hline
\end{tabular}

\section{RESULTS}

The results of our nitrate laboratory test of sweet potato tubers from Ásotthalom- independently of the colour of the tubers showed a negligible amount of nitrate, $3-30 \mathrm{mg} / \mathrm{kg}$ on average, which, in accordance with the relevant health regulations is not dangerous for infants. In case of sweet potato grown on the sandy soil of similar structure and nutrient supply in Vámospércs, a greater nitrate accumulation was observed, however this does not exceed the specified regulation, a maximum of $200 \mathrm{mg} / \mathrm{kg}$ nitrate level. The nitrate content of the orange coloured West African (Cote d'Ivoire) sweet potato tubers that were grown on sandy soils $(60 \%$ sand, $20 \%$ clay, at least $20 \%$ silt, $1.02 \%$ organic carbon, $0.07 \%$ total nitrogen, $\mathrm{pH} 5.46$ ) having different structures

Table 1 Nutrient content of sandy and humus-rich soils in Hungary.

\begin{tabular}{|c|c|c|c|c|c|c|c|c|}
\hline Growing area & $\mathbf{p H}$ & $\begin{array}{c}\text { salt } \\
(\mathrm{m} / \mathbf{m} \%) \\
\end{array}$ & $\begin{array}{l}\text { cohesive } \\
\text { number }\end{array}$ & $\begin{array}{c}\mathrm{CaCO}_{3} \\
(\mathrm{~m} / \mathrm{m} \%) \\
\end{array}$ & $\begin{array}{c}\text { humus } \\
(\mathrm{m} / \mathrm{m} \%)\end{array}$ & $\begin{array}{c}\mathrm{P}_{2} \mathrm{O}_{5} \\
(\mathrm{mg} / \mathrm{kg}) \\
\end{array}$ & $\begin{array}{c}\mathrm{K}_{2} \mathrm{O} \\
(\mathrm{mg} / \mathrm{kg})\end{array}$ & $\begin{array}{c}\mathrm{NO}_{3}-\mathrm{NO}_{2}-\mathrm{N} \\
(\mathrm{mg} / \mathrm{kg})\end{array}$ \\
\hline Ásotthalom & 7.6 & $<0,02$ & 28 & 4.7 & 0.71 & 111 & 72 & 12 \\
\hline Vámospércs & 7.5 & $<0,02$ & 28 & 7.7 & 1.5 & 217 & 75 & 12 \\
\hline Fábiánsebestyén & 7.9 & $<0,02$ & 41 & 5.06 & 4.51 & 458 & $>1000$ & 198 \\
\hline
\end{tabular}

Before planting $400 \mathrm{~kg} /$ ha potassium nitrate $(\mathrm{KNO} 3)$ and 150 $\mathrm{kg} / \mathrm{ha}$ ammonium nitrate limestone $\left(\mathrm{NH}_{4} \mathrm{NO}+\mathrm{CaCO}_{3}\right)$ as basic fertilizer were applied to both cultivation areas. Thereafter, $200 \mathrm{~kg} /$ ha potassium nitrate (KNO3) was applied as liquid fertilizer by spraying during the growing period. Our control examinations were carried out withorange coloured sweet potato tubers originatingfrom West Africa (Cote d'Ivoire). In 2015 and 2016, sweet potatoes were grown on humus-rich, black coloured, cohesive soil, the structure of which contrasted strongly with the sandy soils (Table 1.). After planting, Volldünger 14-7-21(NPK) complex fertilizer was sprayed as liquid fertilizerthree timesin both years. Beetroots were either grown in Hungary on sandy soil with same from the Hungarian types, also showed a very low average value. However, the nitrate content of other sweet potato tubers that were grown in humus-rich soils had multiple NO3NO2-N content then sandy soil and the health risks to infants accumulated. The nitrite content of the sweet potato tubers however was uniformly less than the $0.5 \mathrm{mg} / \mathrm{kg}$ concentration (Table 3 ). In contrast, the nitrate concentration of the collected beetroots showed an extremely high concentration of $800-5600 \mathrm{mg} / \mathrm{kg}$ (Table 4), especially dangerous for infants as it might cause baby blue (methemoglobinemia)syndrome (Hegeshet al., 1982; Bryan et al., 2010). 
Table 3 Values of nitrate-nitrite concentration of sweetpotatotubers $(\mathrm{n}=7)$

\begin{tabular}{cccc}
\hline Growing area & Colour of sweet potato & $\left.\mathbf{~ N O}_{3}{ }^{-} \mathbf{~ m g} / \mathbf{k g}\right)$ & $\mathbf{~ N O}_{2}{ }^{-}(\mathbf{m g} / \mathbf{k g})$ \\
\hline Ásotthalom & orange & $3,14 \pm 0,16$ & $<0,5$ \\
Ásotthalom & purple & $3,48 \pm 0,17$ & $<0,5$ \\
Ásotthalom & white & $27,6 \pm 1,38$ & $<0,5$ \\
Vámospércs & orange & $146 \pm 5,48$ & $<0,5$ \\
Cote d'Ivoire & orange & $4,01 \pm 0,20$ & $<0,5$ \\
Fábiánsebestyén & orange & $314 \pm 9,42$ & $<0,5$ \\
Fábiánsebestyén & purple & $598 \pm 17,9$ & $<0,5$ \\
\hline
\end{tabular}

\section{DISCUSSION}

The nitrate content of West African sweet potato tubers growing in the sandy soil of Hajdúság on the Southern Plains showed a very lowvalue, non-hazardous for human health. The sweet potato tubers grown in sandy soils accumulated the nitrate in a considerably reduced concentration, because only the amount that was necessary for the development of the tubers and other vegetative parts of the plant above ground was available in the soil. It means that sweet potatoes grown in sandy soils-mostly orange coloured varieties - may be suitable raw material for baby food, as well as for homemade carotene-rich purees. In this case the risk of development of methemoglobinemia in the body of infants is negligible. However, in case of sweet potatoes grown in Fábiánsebestyén, toxic nitrate values for infants were detected. It is likely to have happened due to the excessive amount of humus and other nitrogen nutrients (Table 1). They were present in this soil in higher amount than they generally are in sandy soils. It is justified by Mitscherlich-law (1819) that the nutrients, above a certain level, are not linearly related to growth. Excessive amounts of nutrients might cause so called, luxury consumption" in the plant, when the excess nitrogen can accumulate in the form of a toxic nitrate (Lantos, 2015). Sweet potato grown in such type soil is not a suitable raw material for baby food and homemade carotene purees. However, it does not mean danger to babies older than 8 to 10 months, nor to children and adults. It is notable information that sweet potato also yields well in humus-richsoils (average $4.8 \mathrm{~kg} / \mathrm{m} 2$ ). Growing is absolutely safe and profitable in sandy soil and other loose soils on small plots in the region of the South Plains of the Carpathian Basin. Apart from that, when selling sweet potato, it should be compulsory to inform customers about the origin of the tuber and its nitrate-nitrite content. The possibility of nitrate poisoningof infants could be prevented in this way.

Table 4 Values of nitrate-nitrite concentration of beetroots $(n=10)$.

\begin{tabular}{ccc}
\hline Growing area & $\left.\mathbf{N O}_{\mathbf{3}}{ }^{-} \mathbf{~} \mathbf{m g} / \mathbf{k g}\right)$ & $\left.\mathbf{N O}_{\mathbf{2}}{ }^{-} \mathbf{m g} / \mathbf{k g}\right)$ \\
\hline Békéscsaba & $3346 \pm 100$ & $9,09 \pm 0,27$ \\
Csanádalberti & $2479 \pm 74,4$ & $71,5 \pm 2,15$ \\
Hajdúnánás & $2942 \pm 88,3$ & $6,05 \pm 0,18$ \\
Hajdúdorog & $5644 \pm 169$ & $9,42 \pm 0,28$ \\
Miskolc & $4070 \pm 122$ & $16,3 \pm 0,49$ \\
& $2083 \pm 62,5$ & $9,87 \pm 0,30$ \\
& $3166 \pm 95,0$ & $7,55 \pm 0,23$ \\
traded by Hungarian & $2696 \pm 80,9$ & $4,82 \pm 0,14$ \\
supermarkets & $803 \pm 24,1$ & $6,57 \pm 0,20$ \\
& $4050 \pm 122$ & $9,17 \pm 0,28$
\end{tabular}

Table 5Nitratecontent of vegetables(takenfromBryan NS and Hord NG (2010).

\begin{tabular}{|c|c|c|}
\hline nitrate & $\begin{array}{l}\text { content (per kg } \\
\text { freshvegetable) }\end{array}$ & commonvegetables \\
\hline veryhihg & $2500 \mathrm{mg} / 40 \mathrm{mmol}$ & $\begin{array}{l}\text { beetroot and beetrootjuice, } \\
\text { celery, lettuce, rocket, spinach }\end{array}$ \\
\hline hihg & $\begin{array}{c}1000-2500 \mathrm{mg} / 18- \\
40 \mathrm{mmol}\end{array}$ & $\begin{array}{l}\text { Chinesecabbage, celeriac, } \\
\text { endive, leek, parsley, kohlrabi }\end{array}$ \\
\hline moderate & $\begin{array}{c}500-1000 \mathrm{mg} / 9-18 \\
\mathrm{mmol}\end{array}$ & cabbage, dill, turnips, carrotjuice \\
\hline low & $\begin{array}{c}200-500 \mathrm{mg} / 3-9 \\
\mathrm{mmol}\end{array}$ & $\begin{array}{c}\text { broccoli, carrot, cauliflower, } \\
\text { cucumber, pumpkin, V8 } \\
\text { vegetablejuice, }\end{array}$ \\
\hline verylow & $<200 \mathrm{mg} /<3 \mathrm{mmol}$ & $\begin{array}{l}\text { asparagus, artichoke, broadbeans, } \\
\text { greenbeans, peas, sweetpepper, } \\
\text { tomato, watermelon, tomato, } \\
\text { sweetpotato, potato, garlic, } \\
\text { onion, eggplants, mushroom }\end{array}$ \\
\hline
\end{tabular}

Beetroot - regardless of growing area, nutrient supply and soil types - contains nitrate in such high concentration that is not recommended, moreover it is dangerous raw material for baby food, as well as for homemade carotene purees. However, the high nitrate content is not dangerous for children and adults. Due to its other essential nutrition values, beetroot is recommended for children and adults for regular consumption.We cannot rule the possibility that the sweet potato will be one of the safe raw material of homemade carotenoid-rich baby food in EU.

In our opinion, the attention of mothers should be drawn to the hazard of home-made puree of carrot and beetroot raw materials, in media, in child health centres and during the work of the nurse service. The purple coloured sweet potato could take the place of the beetroot, while the orange coloured sweet potato could replace the carrot as raw material in homemade carotene puree in the future.

\section{Acknowledgements}

We would like to thank Dr. FondioLassina and Dr. Dibi Konan researchers from Cote d'Ivoire for their help in preparation of our work. Also thanks to PolgárTiborné head of laboratory and the staff of NÉBIH in Szolnok for their assistance in nitrate-nitrite statements.

\section{References}

Balázs S. (1994): Zöldségtermesztőkkézikönyve. Libatopfélék: A cékla. http://www.tankonyvtar.hu/hu/tartalom/tkt/zoldsegtermes ztok/adatok.html

Bryan, N.S., Hord, N. G. (2010): Dietary nitrates and nitrits: the physiological context for potential health benefits. In: Bryan N.S. (ed) Food nutrition and the nitric oxide pathway: biochemistry and bioactivity. Destech. Pub. Inc.: Lancaster, PA, 59-77.

Georgiev, V. G., Weber, J., Kneschke, E-M., Denev, P.N., Bley, T., Pavlov, A.I. (2010): Antioxidant activity and phenolic content of betalain extracts from intact plants and hairy root cultures of the red beetroot (Beta vulgaris var. Detroit dark red). Plant Foods for Human Nutrition. 65(2): 105-111.

Hegesh, E.,Shiloah, J. (1982): Bloodnitratesand infantilemethemoglobinemia.ClinChimActa.27;125(2):10 7-115. 
Hermann, K. (1995): Inhaltstoffe der Möhren. Die IndustrielleObt- und Gemüseverwertung. 80(7): 266-274.

Lantos, F., Papp, Z., Szücs, B., Hódiné, SZ.M. (2016): Agrochemicaleffect of bacteria fertilizer on carrot (Daucuscarota L.) cultivation. Russian Journal of Agricultural and Socio-Economic Sciences. 8(56): 99103. https://rjoas.com/issues/2016-08.pdf

Lantos, F. (2015): Agrochemistry for Bsc students. SzegediTudományegyetem-NemzetiKulturálisAlap. ISBN 978-963-306-400-9. https://www.researchgate.net/profile/FerencLantos/public ation/292919028

Loebenstein, G.,Thottapphilly, G. (eds. 2009): The sweetpotato. Springer Science+Business Media B.V. DOI. 10.1007/978-1-4020-9475-0-1.

$\begin{array}{llll}\text { Metlickij, } & \text { L. } & \text { V. } & \text { (1975): }\end{array}$ gyümölcsökészöldségekbiokémiája. MezőgazdaságiKiadó, Budapest.

Mitscherlich, E. (1819): Über die Kristallisation der Salze in denen das Metall der Basis mitzweiProportionenSauerstoffverbundenist.

Abhandlungen der Akademie der Wissenschaftenzu Berlin, Jg.1818-1819, 427-437.
PolgárTné., Pásztor L. (2013): Növény, növényialapútermékekextraktumánaknitritnitráttartalommeghatározásáról $\quad 25-250 \quad \mathrm{mg} / 1$ koncentrációtartománybanFIAStar 5000 analizátorral. Validálásijegyzőkönyv. NÉBIH SzolnokiTalajvédelmiLaboratórium.

Uzoni

$\mathrm{H}$.

Sárgarépafajtáknálalkalmazotteltérőtermesztéstechnológi ákhatása a beltartalmiértékekre. PhD értekezés. SzentIstvánEgyetem, KertészettudományiDoktoriIskola. http://phd.lib.uni-corvinus.hu/379/

Tulupov, V. P., Prikhodko, E. I., Fomichenko, E. I. (2001): Toxicological and hygienic assessment of nitrates in food products. VoprosyPitanija. 70 (2): 4-32.

USDA (2016): National Nutrient Database for Standard Reference. Release 28. Retrieved december, 2016:https://ndb.nal.usda.gov/ndb/

\section{How to cite this article:}

F. Lantos et al(2017) ' Examination of nitrate-nitrite (NO3-NO2) accumulation of beetroot and sweet potato, in regard to the development of the methemoglobinaemiasyndrome', International Journal of Current Advanced Research, 06(03), pp. 2755-2758.

DOI: http://dx.doi.org/10.24327/ijcar.2017.2758.0099 